\title{
Are Mass Media and ICTs associated with Inequality and Poverty?
}

\author{
Sanghamitra Bandyopadhyay \\ Queen Mary University of London
}

March 2014

\begin{abstract}
I examine associations of mass media and information and communications technologies (ICTs) with inequality and poverty. I find that newspaper circulation has a robust negative association with inequality. Radios and TVs also have a negative association with poverty. ICT expenditures (as a percentage of GDP) have a negative association with poverty. An ICT index is constructed which also has a negative association with poverty. An instrumental variable analysis confirms the robust negative association between newspaper circulation and inequality.
\end{abstract}

Correspondence: School of Business and Management, Queen Mary, University of London, Mile End Road, London, E1 4NS

email: s.bandyopadhyay@qmul.ac.uk

Keywords: Information and Communications Technologies, Mass Media, Economic Development, Poverty, Inequality

JEL Classification: D30 D80 O1 O57 


\section{Introduction}

The rise of mass media as an indispensible accessory of modern society's access to information has been phenomenal. The availability of information is crucial for efficient decision making by citizens and consumers (Stigler 1961, Stiglitz 2000). For the voter, information about government actions and political candidates is essential for accurate voting choices. Likewise, consumers and investors require information to purchase products and securities.

Access to information is, however, circumscribed by the instruments that are made available to the citizen. Less developed economies particularly suffer from the lack of adequate communications technologies. While access to communications infrastructure and information is largely asserted to be a prerequisite for growth and productivity, there is little empirical evidence which establishes this fact. This paper empirically investigates the association of Information Communications Technologies (hereafter ICTs) and mass media as instruments of access to information, with inequality and poverty.

The impact of ICTs and telephony, is a double edged innovation - one which results in both driving economic growth and in increasing spatial and individual inequalities. While increasing returns and technological progress are conceptually distinct, both theory and evidence seem to suggest that they often come together and result in technological lock-in (David 1985), such that technologies that have an initial advantage tend to endure. Prominent theories on the sources of economic growth reinforce such concerns. The 'weightless' properties of such technologies, with little regard for geographical barriers (Quah 2001a, b) enhance their rapid spread. These properties, however, due to unequal adoption rates, are predisposed to result in rapid increases in spatial and individual inequalities. Thus, in an LDC context, concentration in telephony and ICT penetration is likely to wedge the urban and the rural areas apart, as well as the rich and poor. Skill- 
biased technologies such as those engendered by development of ICTs may also result in high wage inequalities - studies of the US increasing wage gap evince that skill-biased technological change (as a consequence of the increasing computerisation of the US work force) is an important driving force of US wage inequality (Acemoglu and Autor (2010), Autor and Dorn (2009), Autor, Katz and Krueger (1998), Berman et al (2005), Goldin and Katz (1996, 2008), DiNardo and Pischke 1997). The emerging job polarisation is on the rise - ICTs are complementary with human capital and rapid falls in quality-adjusted ICT prices have therefore increased skill demand. There is a large body of literature broadly consistent with this notion.

The task-based theory predicts that ICT improvements increase demand for the most educated (complementing their non-routine cognitive tasks), reduce demand for the middle educated (as it substitutes for routine tasks) and has ambiguous effects for the least educated. Michaels et al. (2013) conclude that technical change has raised relative demand for college educated workers and, consistent with the ICT-based polarisation hypothesis, this increase has come mainly from reducing the relative demand for middle-skilled workers rather than low-skilled workers.

The impact of mass media, however, is less selective on its target audience and not likely to directly accentuate spatial or individual inequalities in the manner of ICTs. Its development and penetration is endogenous in a manner that ICTs are not in that the quality of news generated by the media industry is also dependent of how the government treats the media industry. Deeper media penetration, unlike ICTs, has no unequal effects in its impact. On the other hand, the underdevelopment of media is often a consequence of governments attempting to evade scrutiny from poor delivery or non-delivery of public goods, or government failure. Mass media functions to enhance citizens' abilities to scrutinise government actions. 
I use OLS to show that newspaper circulation is significantly associated with lower inequality. Radios and TVs are also found to be significantly associated with lower poverty.

I obtain mixed results with ICTs and telephony. I find robust evidence of the negative association of ICT expenditures with poverty. I also construct an ICT infrastructure index and find that its association with inequality varies with the sample chosen - it is positively associated with inequality for the sample with both developed and developing countries, but not robustly associated with inequality for the developing country sample.

To confirm these results, I undertake an instrumental variable analysis for newspaper circulation, using three different instruments of press freedom and legal rights for information. The results affirm that there exists a negative relationship between inequality and newspaper circulation.

The rest of the paper is organised as follows. In Section 2 the current literature relating to mass media and ICT/telephony is discussed. Section 3 discusses the data and presents the empirical strategy and Section 4 presents the results. Section 5 deals with potential endogeneity with an instrumental variable analysis. Section 6 concludes.

2. Mass Media and ICT

\subsection{Political Accountability}

\subsubsection{Political Mechanisms}

Despite the obvious justifications that mass media creates a more educated and responsive citizen, it is only recently that the political economy literature has seriously begun to address these issues. While most countries have media in some form or another, there is no guarantee that it is a successful vehicle of information. This is affected by a variety of government actions - ranging from policy decisions affecting the regulation and 
entry and ownership of media on the one hand, to bribery and threats to the media bodies on the other. Besley and Prat (2001) study the determinants and the consequences of captured media, and find that capture is more likely if there is more state ownership of newspapers and there is greater concentration in ownership of newspapers. Petrova (2008) focusses on media misreporting, and explains media bias by conscious manipulation by media owners or editors and finds that it has an impact on public expenditures on education and health. Corneo (2006) finds that a higher concentration in firm ownership to be likely asssociated with higher media bias and lower welfare. Baron (2006) also explains persistent media bias that originates with private information obtained by journalists and persists despite profit-maximizing news organizations and rivalry from other news organizations.

\subsubsection{Corruption}

The existence of an active mass media body is usually seen to be associated with an active democracy. A small but growing cross country literature connects the incidence of a free press and the political framework that accompanies it. There are though countries which are democratic in structure but have low press freedom, especially in the developing world. Brunetti (2003) and Ahrend (2002) find robust correlations between press freedom and corruption. Djankov et al. (2003) also uncover robust cross-country evidence of state ownership of the media to be negatively correlated with a number of measures of good governance. Using a panel of 16 Indian states, 1958-1992, Besley and Burgess (2001) find that Indian state governments provision of public food and calamity relief expenditure is more responsive to falls in food production and crop flood damage in states where newspaper circulation is high. The role of media in moderating business cycles is examined by Shi and Svensson (2002) - using a panel of 123 developed and developing countries over 
a 21-year period, they indeed find larger political budget cycles in countries where few people have radios.

Greater media outlets on the other hand are found to be encouraging for the emergence of a free press (Besley, Burgess and Prat 2002). Competition, though, may result in two different effects. While Besley and Prat argue that more media outlets are an impediment to politicians trying bribe the media, Mullianathan and Shleifer (2005) argue that greater competition could result in newspapers (or other media forms) printing or broadcasting stories which confirm readers prior opinions rather than presenting the real facts. Other lines of research investigate governments incentives to engage in corruption in the presence of independent media bodies (Vaidya 2005).

\subsection{The Effect of ICTs}

While ICTs are a principal carrier of information, its effect on economic development is more tangible than that of mass media - ICT carries with it technology that directly affects economic productivity and growth.

\subsubsection{Growth}

Increased investment in ICT has led to significant increases in economic growth (Haacker and Morsinck 2002, Timmer and van Arky 2005). The US, for instance, had an increase in TFP by one half percentage point per year over the last two decades. Europe's experience with ICT's contribution to economic growth is relatively sporadic. Daveri (2002) reveals that ICT contributions to growth were significant in only 10 countries out of 14 in his study. In only 6 of these, was ICT related capital-deepening associated with greater aggregate total factor productivity or growth in labour productivity. Among the newly 
industrialised economies in East Asia, the deepening of ICT has been of significant importance, particularly in production - $28 \%$ of their manufacturing exports are ICT products (Kenny 2003). The contribution of ICT related capital-deepening in Japan contributed to increasing growth by one half to three quarters

\subsubsection{Inequality}

What prominently distinguishes the outcomes of ICTs as different from other forms of information carriers is that on the production front it is pervasively characterised by increasing returns. Arthur (1994) and Krugman (1991) emphasise that the predominance of increasing returns in a certain industry leads to spatial agglomeration, in a manner similar to how technological lock-in sets in. From this point of view, ICTs are no different from other industries - the location of geographic clusters simply reflects the high skilled and fast-producing nature of the technology. ICT clustering is more pronounced in the EU than in the US (Koski et al. 2000, Quah 2001a). Similarly, unequal access to ICTs and thus information, may exacerbate already existing individual inequalities.

Combining all these issues, one is prompted to ask whether ICT investment is just growth spurring or inequality increasing, or both. Some casual empiricism as discussed above suggests both, but its effects are yet to be empirically established. While the phenomenon of spatial agglomeration is clearly understood in the literature, whether it is associated with increasing individual inequalities is not clear. ${ }^{1}$ The empirical analysis that follows attempts to uncover any such correlations between various development outcomes discussed above and ICTs. 
3. Data and Empirical Strategy

This section discusses the data on ICTs, media, press freedom, the models estimated in the empirical analysis, and explains the empirical methodology used. The database has been put together from a variety of sources, each to be described in turn. Tables 1 and 2 present the variable's sources and their summary statistics, respectively.

[Insert Table 1 and Table 2 here]

\subsection{Measures of Mass Media Penetration}

Mass media penetration is measured by using the number of newspapers in circulation, and the ownership of radios, and televisions, per 1,000 people. The principal data source has been the World Bank Indicators data base.

\subsection{Measures of ICT and Telephony}

The data has been compiled from the World Bank indicators data set (2004). The variables for which I have obtained maximum coverage of countries are the following:

- Mobile phones (per 1,000 people)

- Internet Users (per 1,000 people)

- ICT expenditure as a percentage of GDP

- Fax machines (per 1,000 people)

- Telephone mainlines (per 1,000 people)

- Telephone mainlines per employee 
- Telephone revenue (per 1,000 people)

- Number of personal computers per 100,000 people.

There exist a large number of other ICT indicators, but the country coverage dramatically drops, and therefore not included in the analysis.

To identify the collective effect of the ICT variables, I construct an index of ICT using factor analysis, results of which are presented in Table 3. This technique is a method of data reduction and attempts to describe the indicators as linear combinations of a small number of latent variables. I accept the first factor (f1) to be the general index of ICT and telephony infrastructure (presented later in tables as ICT index), which takes an eigenvalue of over 5. In performing the factor analysis, the data has been normalised for comparability of the numerical values (for example, comparing revenues in US dollars to number of personal computers per 1,000 people). For the estimations I mainly use the first factor, and for robustness I use the second factor f2. I also use the UNCTAD index of ICT diffusion as an alternate indicator of ICT penetration for the year $1997 .^{2}$

[Insert Table 3 here]

3.3. Measures of inequality and poverty

I use the Gini measure (of income inequality) from the WIID2b database published by UNU-WIDER, which documents annual measures of country Ginis, for each year 19921997. I also use two measures of poverty - poverty headcount measured at $\$ 1$ a day, and $\$ 2$ dollars a day, also from the World Bank database.

4. Associations of Inequality and Poverty with ICTs and media 
In this section, I present OLS estimates of the correlations of inequality and poverty with ICT infrastructures and mass media. Given that the nature of the impact of any of these outcomes is unknown, I estimate the models using OLS. Tables 4 and 5 present the results with Ginis (inequality) as the dependent variable, for the full sample and developing country samples, respectively and Table 6 with poverty as the dependent variable.

\subsection{Inequality, and ICTs and Media}

In Tables 4 and 5 I present the results of the associations of media and Telephony/ICT variables with levels of inequality, for the full sample and developing country sample, respectively. The dependent variable is the Gini coefficient, obtained from the UNU-WIDER (2005) database (WIID2b) for years 1992-1997. I estimate models both for the full sample of countries, and the developing countries sample, to observe whether the relationship only holds for LDCs. Figures 1 and 2 present a scatter plot of the relationship between inequality measured by the Gini index, and newspaper circulation per 1,000 people. There is a clear negative relationship. We also obtain a similar negative relationship between poverty and newspaper circulation, as in Figure 2. These scatter plots are already suggestive of the results that are to obtain in the following analyses.

The basic specification that I am estimating is as follows:

$$
\begin{aligned}
& \text { GINI }_{i}=\beta_{0}+\beta_{1} N E W S_{i}+\beta_{2} R A D I O_{i}+\beta_{3} T V_{i}+\beta_{4} I_{\text {ICTindex }}+\beta_{5} \text { BUREAU }_{i}+ \\
& \beta_{6} \text { RULE }_{i}+\beta_{7} T R A D E_{i}+\beta_{8} R I S K_{i}+\varepsilon_{i}
\end{aligned}
$$

Table 1 lists the abbreviations and the sources of the variables in use. $N E W S_{i}$, $R A D I O_{i}$ and $T V_{i}$ represent the incidence of newspapers, TVs and radios in country $i$. The 
ICTindex $x_{i}$ is the index (the first factor, in most cases) that has been estimated using factor analysis in Section 3.2.

I include a number of variables as controls which represent the quality of rule of law and institutions, which engender knowledge and information creation and its spread. Rule of law, presented above as RULE, is a variable obtained from the ICRG, which measures the extent of the citizens capabilities to monitor the extent of corruption. It represents the presence of sound political institutions, a functional legal system and "provisions for an orderly succession of power'. BUREAU accounts for the quality of bureaucracy in the government, also provided by the ICRG based on evaluations from country experts. It indicates the degree of autonomy (of the bureaucracy) from political pressure. Both variables are typically positively associated with lower values of corruption and knowledgebias.

In addition to these I include a number of country-level characteristics which act as proxies of determinants of the quality of rule of law and institutions.

TRADE is a proxy for distortions and restrictions of competition in an economy. It measures the exposure of an economy to foreign trade and is defined as the sum of exports and imports as a percentage of GDP. It has been argued that open countries are subject to larger competitive pressure which reduces monopolistic rents (Ades and Di Tella 1999). ${ }^{3} \mathrm{I}$ also include a variable collected by the ICRG, an index of expropriation risk, named here as RISK, which is scaled such that high values of RISK indicates low risk of appropriation.

Given these factors, one can conjecture that higher incidence of media variables such as newspapers, radios and televisions - and higher access to ICTs - such as higher internet usage, and deeper telecommunications penetration - can be associated with lower levels of inequality. Other country specific controls are also included. Log of GDP per capita and Literacy measure the level of per capita GDP in 1995 (calculated at purchasing power parity US \$), and educational attainment. These both act as proxies for external 
controls - higher levels of GDP per capita and education serve to act to reduce inequality by raising personal incomes.

I envisage the association of any of the media or ICT variables with inequality to be due to media and ICTs facilitating access to information and information technology. Also, societies with higher rule of law indicate the existence of high quality institutions and legal bodies, which can positively affect the impact of ICT and mass media infrastructure on citizen s education or awareness in general. Over time, access to information could translate into higher skills and thereby higher incomes. This impact, if partial across the distribution - that is, positively affects one section of the distribution more than others may wedge the sections apart, resulting in a rise in inequality. This is often the case in developing countries when access to the knowledge-based technology involved is expensive, and infrastructure-intensive.

The reverse may also happen; the knowledge it engenders, may 'equalise' society on some development outcomes (for example, awareness about birth control amongst men and women, brought about by national health programmes, brings down household size and thereby raises household per capita income in poor countries). ICTs and media can therefore serve to work either way on the extent of inequality.

Higher international exposure via TRADE makes the economy competitive, and enhances the quicker spread of information and associated technologies, by bringing down the prices of many of these technologies. As discussed earlier with relation to RULE, its effect may be either positive or negative. In addition, I choose two sets of country-specific controls used by Perotti (1996) and Barro (1999) as has been popularly used in the inequality and growth literature (Banerjee and Duflo (2003)). This is because a central concern for the empirical literature is that any of the right hand side variables used as controls could proxy for omitted variables. The choice of the variables entails judgements about causality that are hard to substantiate. Therefore, I use an already established set of 
controls: those used in Perotti (1996) and those used in Barro (1999). Specifications empirically tested for are repeated with two sets of controls. These specifications are useful benchmarks for two reasons. First, the Perotti specification has been used by most subsequent studies. Second, they represent two extremes, the Perotti specification using the smallest number of control variables and the Barro specification the largest. ${ }^{4}$ The Perotti specification excludes most variables (in particular, investment and government spending) through which inequality could be affected. The variables included are male and female education and the purchasing power parity of investment goods, a measure of distortions. Barro, on the other hand, includes a much larger set of variables through which inequality could be affected - investment share of GDP, fertility, education and government spending. The interpretation of the coefficients in two regressions is therefore slightly different. The results presented in Table 4 allow for both sets of controls. To separate out the associations for developing countries only, I estimate the model for both the full sample of countries and the developing country sample separately, presented in Table 5 respectively.

[Insert Tables 4 and 5 here]

Table 4 presents the estimates for the full sample - Column 1 estimates the basic model, with the individual media and ICT and telephony variables included individually, and the country-level controls BUREAU, RULE, Log of GDP per capita, literacy, TRADE and RISK. I observe that newspaper circulation, TVs and faxes are negatively and significantly associated with inequality. Telephone mainlines are also negatively and significantly associated with inequality. Of the ICT variables, only the number of internet users is observed to be significant and positively associated with inequality. Inclusion of continent dummies in Column 3, and the Perotti controls, reveals both the Africa and 
Latin America continent dummies to be significant. I obtain the same results with the Barro controls (results not presented in Table).

For the estimates in Columns 4 to 6 , I replace the individual variables with the ICT/telephony index estimated by factor analysis - Columns 4 and 5 present the results using the first factor obtained from the factor analysis exercise, with the Barro and Perotti controls; the ICT/telephony index is not significant when included as levels, but is positive and significant when included as a squared variable. Other media variables - newspapers and TVs continue to be negative and significant. I replace the first factor by the second factor obtained from the factor analysis as the ICT index in Column 6 (using Barro controls) - here I obtain a significant and positive co-efficient for the ICT index. In all the specifications, the continent dummies are significant.

Table 5 presents the estimates for the developing countries sample - Columns 1 and 2 present the results for inclusion of the individual media and ICT/telephony variables, with the Barro and Perotti controls respectively. Newspapers are negatively and significantly associated with inequality, but TVs are no longer significant. Continent dummies are significant for both specifications. I replace the individual media and ICT variables with the ICT index in Columns 3 and 4 - I obtain a negative co-efficient for the model including the Perotti controls, but it is not significant. I include ICT index (f1) squared and f2 as well, and obtain no significance (result not reported in table). The same models were tested using the UNCTAD ICT diffusion index as well, and no significant results were obtained (results available from author).

In both sets of models for full sample and developing country sample, there have been mixed outcomes for the country level controls - RULE for the full sample has been negative and significant throughout, likewise mostly for RISK, but not so for the developing country sample. BUREAU has also been positive and significant under some specifications for the developing country sample, while TRADE and literacy even rarely so. 
Ln GDP for several specifications is positive and significant under both the full sample and developing country sample.

Finally, the results tabulating the regressions of inequality on mass media and ICT indicators in Tables 4 and 5, established two sets of relationships. For the full sample of countries, the ICT index is found to be positively associated with inequality, while for the developing country sample, it is either not significantly associated, or weakly negatively associated with inequality.

To affirm this non-linear relationship between inequality and the ICT index, I plot some kernel regressions of inequality (Ginis) on the ICT index to ascertain the non-linear nature of this relationship. The non-linear relationship between growth and development indicators and inequality is well documented - from Kuznets's inverted U-curve hypothesis, to recent studies on inequality and growth (Banerjee and Duflo 2002, Quah 2002). It is well possible that a similar "stage of development" -specific relationship exists for inequality and the ICT infrastructure index.

Kernel regressions of the Gini on the ICT index are plotted for both f1 and $\mathrm{f} 2$ (the first two factors from the factor analysis exercise retained as indices of ICT) in Figures 3 to42. I use two types of kernel estimators, the Epanechnikov estimator, and a quartic estimator (not presented) - both reveal similar non-linearities in the relationship between ICT indices and the Gini. For the regression of the Gini on the ICT index first factor, f1 in Figure 2, I observe that for lower values of ICT index f1, the relationship is positive, and for higher values of ICT index f1, it is negative. For the regression of the Gini on the ICT index second factor, f2 in Figure 4 I observe a clearer negative relationship, though this negative relationship often switches to a positive relationship for rising levels of ICT index f2. This result is also evinced in our regression models earlier when including a ICT (f1) index squared (or f2) term in addition to f1 (or f2). 
To summarise our results obtained:

- Inequality is found to be negatively and significantly associated with several media variables, most notably with newspaper circulation. Newspaper circulation is negative and significant under all specifications: for the full sample and developing country sample, and including Perotti and Barro controls. TVs are also found to be negatively associated with inequality, though the level of significance varies with the model and controls included.

- Inequality is also found to be significantly associated with the ICT index under several specifications for the full sample. For the full sample models, it is positive and significant, particularly for the models where it is included as with higher orders, but for the developing country sample it is not significant. The relationship is sensitive to specification, and could be due to non-linearities in the relationship, as evinced by the kernel regression estimates (Figures 3 and 4).

\subsection{Poverty, ICTs and Media}

The next relationship that I will be investigating is the association of the media and ICT variables with poverty. The main model estimated is

$$
\begin{aligned}
& \text { POVERTY } Y_{i}=\beta_{o}+\beta_{1} \text { NEWS }_{i}+\beta_{2} R A D I O_{i}+\beta 3 T V_{i}+\beta_{4} \text { ICTindex }_{i}+\beta_{5} \text { BUREAU }_{i} \\
& +\beta_{6} \text { RULE }_{i}+\beta_{7} T R A D E_{i}+\beta_{8} R I S K_{i}+\varepsilon_{i}
\end{aligned}
$$

Poverty is measured using two definitions of poverty - the one dollar a day definition (poverty headcount ratio at $\$ 1$ a day (PPP) (\% of population)), and the two dollar a day definition (poverty headcount ratio at $\$ 2$ a day (PPP) (\% of population)) of the World 
Bank over the years 1992 - 1997. I also estimated the models with the poverty headcount ratio at national poverty line (\% of population), but due to the number of observations being very low, most specifications did not run. For this analysis I only consider the sample of LDCs (83 countries). Here again I use the same set of controls as determinants of poverty as before, via the same political economy routes. Controls of BUREAU and RULE account for good governance, and provide the institutional set up for growth and economic development. TRADE and RISK ensure the competitiveness required for economic growth and development, thereby lowering levels of poverty. One would expect a negative association of poverty with all of these four controls. Country level characteristics of log of GDP and literacy are also included, and are expected to be negatively associated with poverty.

In Table 6, Column 1 presents the results of the basic specification with newspaper circulation, radios, and TVs as the media variables, and the ICT and telephony individual variables, using the one dollar a day definition of the poverty measure. Due to the small sample size I only include the Perotti controls, and the country-specific characteristics. Newspaper circulation is not significantly associated with poverty - this result holds for all specifications, barring Column 2 where it is positively associated with poverty. This result is not observed elsewhere. Radios are however, significant and negative for all models tested. This is observed for all the models presented, and also for any other model that has been tested. TVs are not significant, and this holds for most specifications using the one dollar a day measure of poverty. None of the individual ICT variables are significantly associated with poverty, but telephone revenues is positive and significant. In Column 2, I also observe mobile telephony to be negative and significant as well. This is a significant result, as the adoption of mobile telephones by the poor in developing countries is quite high. Most poor households can afford a pay-as-you-go mobile telephony due to the competitive rates provided by the service providers. TVs and newspapers are significant 
and positive - this result is sensitive to the specification, and does not hold for the rest of the results presented. This result also accords with the notion that they are both cost intensive and thus are less affordable by the poorer sections of the income distribution.

[Insert Table 6 here]

In the following two columns, I replace the individual ICT variables with the ICT index - I have tested with both ICT index (f1) and ICT index (f2) factors, and higher order terms (squared terms), the latter not presented, and it has not been significant in any of the specifications. Radios continue to be negatively and significantly associated with poverty. The continent dummies included in Column 4 are not significant - this is observed for all specifications estimated.

Columns 5 to 7 present the results using the two dollars a day measure of poverty. I again observe the negative and significant association of radios with poverty, but also observe that TVs is also negative and significant. This result holds for all specifications tested with the two dollar a day measure of poverty. Of the ICT variables tested, I observe that ICT expenditure as a percentage of GDP to be negative and significant. Internet users are also observed to be negative and significant - this result holds for all specifications. None of the telephony variables are significant. On replacing the individual ICT variables with the ICT index, I do not obtain a significant co-efficient. It is possible that the ICT variables that are individually significant are proxying for the level of development.

To summarise our results:

- I find that radios are significantly and negatively associated with poverty. This result holds for all the models that have been estimated. TVs are also observed to be negative and significant particularly so for the models using $\$ 2 /$ day poverty measure. 
- The ICT index is not significantly associated with poverty. Of the individual ICT variables, ICT expenditures are negatively and significantly associated with poverty under some specifications.

5. Issues of Endogeneity: Role of mass media

One major issue to deal with is that of the potential problem of reverse causality between the development outcomes, inequality and poverty, and that of the media and ICT variables. In this section we discuss the potential sources of endogeneity, and then follow it with an instrumental variable analysis for the media variable, newspaper circulation (per 1,000 people). Of course, finding an appropriate instrument for either mass media or ICT variables is extremely difficult, but the instruments used below for newspaper circulation, in particular, provide us with some robust instrumental variable results.

There are two sources of endogeneity here - both ICT and telephony variables, and mass media, have a two-sided impact upon the development outcomes of inequality and poverty. As discussed earlier, the effect of ICT and telephony variables has a double edged effect. On the one hand, they have a "growth" effect: ICT and telephony are infrastructure variables, and thereby contribute to economic growth. In addition, due to the "weightless" nature of ICTs, their spread is speedy and it disregards physical barriers, enhancing their "growth effect". One could therefore expect, on the one hand, the impact of ICTs and telephony to be growth enhancing and poverty reducing (in the medium to long term). On the other hand, there is a distribution specific effect of ICTs and telephony, in that they are cost intensive for adoption. Even with the competitive prices of ICTs and their 
weightless nature, in developing countries access to these technologies is out of reach of the poor (though, this is not the case for mobile telephony in LDCs). Therefore, one could conjecture that in industrialised countries, the ICT and telephony penetration facilitates the spread of information, and will likely bring down the extent of income inequality. The same process, though, in developing countries, will push the rich and the poor apart. However, the extent to which the process of inequality increase pans out in developing countries depends upon adoption rates. Adoption and the spread of ICTs and telephony is still relatively in LDCs compared to industrialised countries, hence, we may not observe a short term rise in inequality in LDCs even if ICTs and telephony penetration were to occur.

Similar endogeneity can be envisaged with the case of mass media and the development outcomes of inequality and poverty. Mass media provides crucial information to the median voter and thereby influences decisions on demanding redistributive policies. This brings down inequality. It also creates a more educated society and thereby contributes to economic growth and rising per capita incomes. This also brings down inequality in the long run. One would also expect, however, that the instruments of media (such as newspapers, radios and TVs) themselves are not responsible for creating an educated voter or citizen. It is the nature of the news provider (public or private, national or foreign owned), and the quality of information (unbiased or biased) that is being broadcast that ultimately determines the nature of information provided. On the one hand, media bias (see Djankov et al 2005) is commonly understood to be less pervasive if the news providing bodies in a country (or region within a country) are competitive - in other words, single bodies such as the state media, in the absence of competing private media bodies is often seen as providing "propaganda". On the other hand, in a system where both public and private media bodies co-exist, the news coverage of public bodies is often deemed to be more reliable (for example, the case of the BBC in the UK, Doordarshan in India, PBS in the US). 
Irrespective of the number and the ratio of public to private media bodies, what is understood to matter the most is the legal framework which ensures transparency in the provision of information. To this effect, several indicators of the freedom of information and transparency have been compiled by a number of civil society organisations. I use three main indicators of press freedom and transparency as instruments for newspaper circulation. Freedom House has compiled an index of press freedom, and ranks countries according to their index, the Freedom of Press Index, which is an annual survey of media independence in 197 countries and territories. Data for the years 1992 and 1993 are not available (the index starts from 1994), so our variable starts in 1994. In addition, to account for a broader definition of information bias and government actions against free press, I use the Reporters Without Borders index of press freedom using data on journalists arrested and murdered, in addition to standard indicators of press freedom. Their index starts in 2002 for most countries, otherwise from 2003, and runs till 2010. Given that this is a slow moving variable I have used the index from 2002 to 2007 (or 2003 to 2008) to represent years 1992 to 1997. (I have used different starting points for the years and the results obtained are identical in terms of their significance). The index covers all countries in the dataset, except for Bahrain. There are two indicators provided, a score, and a ranking on the basis of the score - I use of the log of the score provided.

I use a further index of quality of information provided by media, called the Right to Information Index, compiled by the Global Right to Information ${ }^{5}$. The RTI Rating is a system for assessing the strength of the legal framework for guaranteeing the right to information in a given country. The focus of the index is therefore on gauging the legal framework to access to information, and not on the "quality" of implementation of the legal framework. Over time a strong access-to-information law can contribute to advancing openness and help those using it to defend and promote the right of access to information. 
The index is compiled by using 61 indicators measuring a wide range of international standards and laws on the right to information. For the estimations in the paper, to make the RTI score values comparable to other indicators, I have used the natural logarithmic value of the index.

\subsection{Results}

We now undertake an instrumental variable (IV) estimation using the three instruments described above. The results of the estimation using Two Stage Least Squares is described in Table 7 for the relationship between inequality and the ICT and media variables. In Table 7 Panel A I present the first stage results for the determinants of newspaper circulation (per 1,000 households). Here I regress newspaper circulation on all three instruments, namely the Freedom of Press index, log of RTI index and the log on Reporters Without Borders score alongside the other cross-country controls used in the estimation of equation (1). Newspaper circulation is positively and significantly associated with log of RTI index and the log of Reporters Without Borders score instruments for all six regressions, using both Perotti and Barro controls separately. The other controls used are significant at several levels of significance, and in the expected directions. The CraggDonald statistic in all six regressions is greater than 10 suggesting that the instruments are not weak (Staiger and Stock 1997).

I now estimate equation 1 as the second stage regression and present the second stage results in Table 7 Panel B. The results are just as strong as in Table 4; in all cases the size of the co-efficient for newspapers is greater than before. Due to the small number of observations, I do not present the results for the developing country sample. For the same reason the results with poverty are not presented.

[Insert Table 7 here] 
6. Conclusion

Mass media and ICTs are two important vehicles of information in developing and developed countries alike. In this paper I present some robust evidence of some associations of ICTs and mass media with inequality and poverty.

I observe that inequality (measured with the Gini index), is negatively associated with newspaper penetration - this is one of the most robust results of all estimates. The ICT and telephony variables and the ICT index have mixed outcomes in their associations with inequality - for the full sample there exists a positive association, and a weak association (mostly negative) for the developing country sample. ICT expenditures as a percentage of GDP are found to have a negative association with inequality. For poverty, the most prominent result observed was the negative association with the incidence of radios and TVs - this result has been robust to all specifications tested, particularly for radios.

I also undertake an instrumental variable analysis for the newspaper circulation variable, using three instruments. I continue to find robust evidence that newspaper circulation is robustly negatively associated with inequality. In other words, higher newspaper circulation is found to be associated with lower levels of inequality.

There are several avenues for future research - testing for specific political economy routes of causality for any of these associations will take this literature further. The literature on media capture and bias (Corneo 2006, Petrova 2008 for effects of income inequality on media bias, for example) addresses some of the issues that are tested here. Causality related to the effects of information infrastructures on inequality and poverty require micro-level empirical surveys, which the cross-country macro-approach adopted in this paper can only partially address. Country-specific micro-studies will therefore allow researchers to test for causality. 
The role of ICTs in developing countries is much discussed in policy spheres; studies which examine the micro-level impact of these infrastructures will shed light on their effectiveness on local level welfare. With the role of media bias being much studied in a cross-country context, more research on its impact in developing countries in particular, in light of their weak legal institutions would contribute to the developing country literature specifically.

With the empirical literature on relationships between information infrastructures and development outcomes still at its early stages, the evidence obtained in this paper is convincing that there exists a significant association between media and communications infrastructures, and inequality and poverty. 
Bibliography

Acemoglu, D. (2002). Technical Change, Inequality, and Labour Market. Journal of Economic Literature, 40(1), pp. 7-72.

Acemoglu, D., and D. Autor (2010). Skills, Tasks and Technologies: Implications for Employment and Earnings, Handbook of Labor Economics Volume IV, edited by David Card and Orley Ashenfelter, Princeton: Princeton University Press.

Ades, A., and Di Tella, R. (1999). Rents, Competition and Corruption. American Economic Review, 89(4), pp. 982--993.

Ahrend, R. (2001). Press Freedom, Human Capital and Corruption. DELTA Working Paper No. 2002-11.

Arthur, B. W. (1994). Increasing Returns and Path Dependence in the Economy. Ann Arbor: University of Michigan Press.

Autor, D., L. F. Katz, and A. B. Krueger (1998). Computing Inequality: How Computers have Changed the Labour Market. Quarterly Journal of Economics, 113(4), 11691214.

Autor, David and David Dorn (2009). Inequality and Specialization: The Growth of LowSkill Service Jobs in the United States. NBER Working Paper 15150.

Bardhan, P. (1997). Corruption and Development. Journal of Economic Literature 35(3), pp. $1320-1346$.

Baron, D. (2006). Persistent Media Bias. Journal of Public Economics, 90(1-2), pp. 1-36.

Barro, R. J. (1999). Inequality, Growth, and Investment. Working Paper 7038, National Bureau of Economic Research, March.

Berman, Eli, Rohini Somanathan and Hong Tan. (2005). Is skill-biased technological change here yet? Evidence from Indian manufacturing in the 1990s, Annales d'Economie et de Statistique, 79-80, pp. 299-321. 
Besley, T., and J. McLaren (1993). Taxes and Bribery: the Role of Wage Incentives. Economic Journal, 103(416), pp. 119-141.

Besley, Timothy and R. Burgess (2002a). The Political Economy of Government Responsiveness: Theory and Evidence from India. Quarterly Journal of Economics, 117(4), pp. 1415-1451.

Besley, T, R. Burgess and A. Prat (2002b). Mass Media and Political Accountability, in: R. Islam (ed.): The Right to Know: Institutions and the Media, (Washington DC: World Bank), pp. 45-60.

Brunetti, A and B. Weder (2003). A Free Press is Bad News for Corruption. Journal of Public Economics, 87(7-8), pp. 1801-1824.

Corneo, G. (2006). Media Capture in a Democracy: The Role of Wealth Concentration. Journal of Public Economics, 90(1-2), pp. 37-58.

Coyle, D. (2004). Economic and Social Impact Project: Mobile Telephony in the Developing World: A Literature Review. Mimeo. Department for International Development, U.K.

Daveri, F. (2002). The New Economy in Europe: 1992-2001. Oxford Review of Economic Policy 18(3): pp. 345-362.

David, P.A. (1985). Clio and the Economics of QWERTY. American Economic Review, 75(2): pp. 332-337.

Deninger, K. and L. Squire (1996). Measuring Income Inequality: A New Database. World Bank Economic Review, 10(3), pp. 565-591.

DiNardo, J E., and J-S. Pischke (1997). The Returns to Computer Use Revisited: Have Pencils Changed the Wage Structure Too? Quarterly Journal of Economics, 112(1), pp. 291-303. 
Djankov, S., C. McLeish, T. Nenova, and A. Shleifer (2003). Who Owns the Media? Journal of Law and Economics, 46(2), pp. 341-81.

Easterly, W. and Levine, R. (1997). Africa s Growth Tragedy: Policies and Ethnic Divisions. Quarterly Journal of Economics, 112(4), pp. 1203-1250.

Goldin, C and L. F. Katz (1996). Technology, Skill and Wage Structure: Insights from the Past. American Economic Review, 86(2), pp. 252-257.

Goldin, C and L. F. Katz (2008). The Race Between Education and Technology. Cambridge, MA: Harvard University Press.

Haacker, M and J. Morsinck (2002). You Say You Want a Revolution: Information Technology and Growth, IMF Working Paper \#WP/02/70.

Kelly, N. J. and P. Enns (2011): Inequality and the Dynamics of Public Opinion: The SelfReinforcing Link Between Economic Inequality and Mass Preferences. American Journal of Political Science, 54(4), pp. 855-870.

Kenny, C (2003). The Internet and Economic Growth in LDCs: A Case for Managing Expectations. Oxford Development Studies, 31(1), pp. 99-113.

Koski, H, P. Rouvinen, and P. Yla-Anttila (2002). ICT Clusters in Europe: The Great Central Banana and Small Nordic Potato. Information Economics and Policy 14(2): pp. $145-165$.

Kreuger, A. (1993). How Computers Have Changed the Wage Structure: Evidence from Microdata, 1984-89. Quarterly Journal of Economics, 108(1), pp. 33-60.

Krugman, P (1991). Increasing Returns and Economic Geography. Journal of Political Economy, 99(3), pp. 483-499.

Mauro, P. (1995). Corruption and Growth. Quarterly Journal of Economics, 110(3), pp. $681-712$.

Mauro, P. (1996). The Effects of Corruption on Growth, Investment and Government Expenditure. Journal of Public Economics, 69, pp. 263-279. 
Mullainathan, S., and A.Shleifer (2005). The Market for News. American Economic Review, 95(4), pp. 1031-1053.

Perotti, R. (1996). Growth, Income Distribution and Democracy. Journal of Economic Growth, 1(2), pp. 149-187.

Petrova, M. (2008). Inequality and Media Capture. Journal of Public Economics, 92(1-2), pp. $183-212$.

Piatkowski, J (2002): The 'New Economy and Economic Growth in Transition Economies, WIDER Discussion Paper 2002/62

Quah, D (2001a). ICT Clusters in Development: Theory and evidence. EIB Papers, 6(1), pp. $85-100$.

Quah, D (2001b). The Weightless Economy in Economic Development, in: M. Pohjola (ed.), Information Technology, Productivity, and Economic Growth: International Evidence (Oxford: Oxford University Press), pp. 72--96.

Rauch, J. and P. Evans (2000). Bureaucratic Structures and Economic Performance in Less Developed Countries. Journal of Public Economics, 75(1), pp. 49-71.

Reinikka, R., and J. Svensson (2005). Fighting Corruption to Improve Schooling: Evidence from a Newspaper Campaign in Uganda. Journal of the European Economic Association, 3(2-3), pp. 259-267.

Shi, M. and J. Svensson (2002). Conditional Political Budget Cycles. CEPR Discussion Paper, No. 3352.

Staiger, D., and J. H. Stock. (1997). Instrumental variables regression with weak instruments. Econometrica, 65: pp. 557-86.

Stapenhurst, R. (2000). The Media s Role in Curbing Corruption. World Bank Institute, The World Bank, Washington DC.

Stigler, G. (1961). The Economics of Information. Journal of Political Economy, 69(3), pp. $213-225$. 
Stiglitz, J. E. (2000). The Contributions of the Economics of Information to Twentieth Century Economics. Quarterly Journal of Economics, 115(4): pp. 1441-1478.

Strömberg, D. (2001). Mass Media and Public Policy. European Economic Review, 45(4-6), pp. 652-663.

Timmer, M. P. and B. van Arky (2005). Does Information and Communication Technology Drive EU-US Productivity Growth Differentials? Oxford Economic Papers, 57(4), pp. 693-716.

UNU (2008). World Income Inequality Database-WIID v2.0c. World Institute for Development Economics Research, United Nations University, Helsinki.

Vaidya, S. (2005). Corruption in the Media s gaze. European Journal of Political Economy, 21(3), pp. 667-687.

Wei, L and D. B. Hindman (2011). Does the Digital Divide Matter More? Comparing the Effects of New Media and Old Media Use on the Education-Based Knowledge Gap, Mass Communication and Society, 14(2), pp.216-35 
${ }^{1}$ Some work in this area has been done on the impact of ICTs on wage inequalities in the US, see Autor et al (1998).

2 The results using the UNCTAD index are not presented in the paper and are available from the author.

${ }^{3}$ A large number of cross country studies investigating differential development outcomes, have often included the extent of cultural diversification as a possible determinant of differential growth and development outcomes. It is purported to affect corruption in particular by impeding competitiveness. Ethnic fragmentation has been included in several specifications but has not shown up to be significant and hence is not presented.

4 The list of variables included in both specifications are as follows: Perotti: Log(GDP(1990), PPP I (1990), male education (1990), female education (1990). Barro: $\log (\mathrm{GDP}(1990)), \log (\mathrm{GDP}(1990))$ squared, government consumption (1990-1995), secondary and higher education (1990), fertility (1990), 1/30*(term of trade(1995)-terms of trade(1990)), rule of law, democracy (1990), democracy (1990) squared, inflation (19901995) and investment share (1990-1995).

${ }^{5}$ The source of this RTI Index is http://www.rti-rating.org/country_data.php. 
Table 1: Variables used in the paper and their sources. All years refer to the period 1992-1997

\section{Variable name}

Average quality of the bureaucracy Average Trade ((Export+Import) /GDP) Average rule of law Risk Premium

Natural Log of GDP, per capita

Education

Latin America dummy

Africa dummy

OECD country dummy

UNCTAD ICT diffusion index

Gini index

Poverty, one dollar a day, head count ratio Poverty, two dollars a day, head count ratio Mobile phones (per 1,000 people)

Internet Users (per 1,000 people)

ICT expenditure as a percentage of GDP

Fax machines (per 1,000 people)

Telephone mainlines (per 1,000 people)

Telephone mainlines per employee

Telephone revenue (per 1,000 people)

Newspaper circulation (per 1,000 people)

Radios, (per 1,000 people)

Televisions, (per 1,000 people)

Freedom of Press Index

Right to Information (RTI) Index

Reporters Without Borders (RWB) Score
Years

1994-1997

all years

all years

all years

all years

all years

all years

all years

all years

all years

1997

all years

all years

all years

all years

all years

all years

all years

all years

all years

all years

all years

all years

all years

1994-1997

1970s onwards

2002 onwards
Source

ICRG

ICRG

WDI 2005

ICRG

ICRG

WDI 2005

WDI 2005

--

$--$

UNCTAD

WIDER

WDI 2005

WDI 2005

WDI 2005

WDI 2005

WDI 2005

WDI 2005

WDI 2005

WDI 2005

WDI 2005

WDI 2005

WDI 2005

WDI 2005

Freedom House

www.rti-rating.org

http://en.rsf.org/ 
Table 2: Descriptive Statistics

Variable

Observations Mean

Std. Deviation Minimum

Maximum

Panel A: Full Sample

$\begin{array}{ll}\text { Gini index } & 491 \\ \text { ICT index (f1) } & 166 \\ \text { ICT index (f2) } & 166 \\ \text { Fax } & 455 \\ \text { ICT expenditure } & 258 \\ \text { Internet users } & 450 \\ \text { Mobiles } & 679 \\ \text { Newspapers } & 627 \\ \text { Radios } & 684 \\ \text { TVs } & 676 \\ \text { Telephone mainlines } & 506 \\ \text { Mainlines/employee } & 654 \\ \text { Mainline revenue } & 639 \\ \text { Average rule of law } & 684 \\ \text { Quality of Bureaucracy } & 684 \\ \text { Risk premium } & 684 \\ \text { Freedom of press index } & 456 \\ \text { RWB score } & 667 \\ \text { RTI score } & 371\end{array}$

44.0

0.0

$-0.1$

10.4

4.6

$455,735.7$

24.8

119.2

429.0

219.8

235.6

90.6

982.4

4.1

3.5

8.6

44.5

2529.2

84.1
12.7

0.9

0.8

17.0

2.0

$2,677,465$

52.4

149.0

477.9

197.5

230.5

71.4

607.9

1.4

1.4

1.7

23.5

2334.0

19.6
18.1

$-1.4$

$-0.8$

0.0

0.3

0.0

0.0

0.1

27.9

0.5

3.2

6.7

8.2

0.0

1.0

1.0

5.0

50.0

37.0
73.9

2.6

6.1

127.0

9.1

$40,000,000$

419.4

818.8

6763.8

854.5

1040.1

360.7

4380.7

6.0

6.0

10.0

100.0

$10,900.0$

130.0

Panel B: Developing Country Sample

Gini index

Poverty $\$ 1 /$ day

Poverty \$2/day

ICT index (f1)

ICT index (f2)

Fax

ICT expenditure

Internet users

Mobiles

Newspapers

Radios

TVs

Telephone mainlines

Mainlines/employee

Mainline revenue

Average rule of law

Quality of Bureaucracy

Risk premium
311

99

99

66

66

281

90

261

475

429

480

472

372

455

441

480

480

480
50.0

18.7

41.8

$-0.7$

$-0.3$

2.5

3.3

$46,263.5$

8.0

50.3

288.8

134.7

143.0

62.0

1033.3

3.5

2.9

8.1
11.0

19.5

27.1

0.4

0.2

4.4

1.4

$141,327.7$

19.9

62.4

353.4

136.6

151.1

48.1

668.6

1.2

1.0

1.8
25.5

2.0

2.0

$-1.4$

$-0.8$

0.0

0.3

0.0

0.0

0.1

27.9

0.5

3.2

6.7

82.0

0.0

1.0

1.0
73.9

73.6

91.7

0.2

0.1

23.6

7.4

$1,310,000$

146.6

435.8

6763.8

808.4

977.5

290.5

4380.7

6.0

6.0

10.0 
Table 3: Factor Analysis

Panel A: Eigenvalues of the factors of ICT variables obtained using Factor Analysis

Factor

Factor1

Factor2

Factor3

Factor4

Factor5

Factor6

Factor7

Factor8
Eigenvalue

4.534

0.416

0.284

0.102

0.054

$-0.053$

$-0.109$

$-0.167$

Panel B: Factor loadings of the ICT variables obtained using Factor Analysis

$\begin{array}{llllll}\text { Variable } & \text { Factor1 } & \text { Factor2 } & \text { Factor3 } & \text { Factor4 } & \text { Factor5 } \\ \text { Mobile phones/1000 people } & 0.721 & 0.240 & -0.175 & 0.026 & -0.134 \\ \text { Internet users/1000 people } & 0.424 & 0.359 & 0.298 & -0.037 & 0.083 \\ \text { ICT expenditures as \% of GDP } & 0.776 & -0.118 & -0.149 & -0.076 & 0.138 \\ \text { Faxes/1000 people } & 0.849 & 0.125 & 0.179 & 0.124 & -0.026 \\ \text { Computers/1000 people } & 0.932 & 0.106 & -0.088 & -0.144 & -0.004 \\ \text { Mainline telephones/ 1000 people } & 0.888 & -0.272 & 0.092 & -0.119 & -0.069 \\ \text { Telephone revenue/1000 people } & 0.742 & -0.016 & -0.212 & 0.188 & 0.067 \\ \text { Mainline telephones/employee } & 0.550 & -0.338 & 0.219 & 0.092 & -0.013\end{array}$

Notes:

Average interim Cronbach's alpha (standardised) $=0.527$

Scale reliability coefficient $=0.899$ 
Table 4: OLS Regressions of Gini Index 1992-1997, for full sample
(1)
(2)
(3)
(4)
(5)
(6)

Controls

Newspapers

Perotti Barro Perotti Barro

Radios

$\begin{array}{lll}-0.058^{* * *} & -0.051^{* * *} & -0.062^{* * *} \\ (0.011) & (0.013) & (0.010) \\ 0.000 & -0.000 & -0.001 \\ (0.000) & (0.000) & (0.001) \\ -0.040^{* * *} & -0.039^{* * *} & -0.024 * * * \\ (0.008) & (0.010) & (0.007) \\ -0.364^{* *} & -0.313^{*} & -0.001 \\ (0.161) & (0.174) & (0.155) \\ 0.172 & -0.08 & -0.88 \\ (0.661) & (0.684) & (0.681) \\ 0.000^{*} & 0.000^{* *} & 0.000^{* *} \\ (0.0000) & (0.0000) & (0.0000) \\ 0.019 & 0.055 & -0.0211 \\ (0.033) & (0.037) & (0.029)\end{array}$

Mobiles

$(0.033)$

(0.037) (0.029)

ICT Index

$$
\begin{aligned}
& -0.178 \\
& (3.082)
\end{aligned}
$$

ICT Index squared

$10.56^{* * *}$

$(2.758)$

ICT Index 2

$\begin{array}{llllll}0.263 & 0.552 & 1.264 & -0.190 & 1.449 * & 0.583\end{array}$

Quality of Bureaucracy

$\begin{array}{lll}(0.917) & (0.982) & (0.854)\end{array}$

$\begin{array}{lll}(0.915) & (0.836) & (0.898)\end{array}$

Average Rule of Law

$-3.639 * * *$

$-2.584^{* * *}-1.412$

$-3.257 * * *$

$-1.078$

$\begin{array}{lll}(0.854) & (0.904) & (0.874)\end{array}$

$\begin{array}{lll}(0.904) & (0.818) & (0.882)\end{array}$

Log GDP/capita

$3.136 * *$

2.495*

0.578

1.301

$3.69 * * * \quad-0.411$

(1.361)

(1.461)

(1.344)

(1.681)

(1.517)

(1.124)

Education

0.0712

0.104

0.133

0.123

$0.383^{* * *} \quad 0.176$

(0.085)

(0.099)

(0.111)

(0.130)

(0.137)

(0.132)

Average Trade

$(0.025)$

$(0.027)$

$0.107^{* * *}$

0.023

$0.131^{* * *}$

$0.084^{* * *}$

Risk Premium

$-0.627$

$-1.758$

(0.028)

$(0.025)$

(0.027)

(0.024)

(1.240)

(1.288)

$-2.14^{*}$

$-0.697$

$-1.321$

$-2.491^{* *}$

Telephone Mainlines

$-0.013^{*}$

(1.286)

(1.076)

(1.157)

Africa Dummy

Latin America Dummy

(0.006)

$\begin{array}{llll}10.8^{* * *} & & 12.47^{* * *} & 10.73^{* * *} \\ (4.046) & & (3.635) & (4.003) \\ 13.0 * * * & & 13.38^{* * *} & 11.9 * * * \\ (2.436) & & (2.203) & (2.317) \\ 55.332^{* * *} & 62.421^{* * *} & -6.272 & 66.715^{* * *} \\ (19.424) & (23.399) & (24.99) & (18.099) \\ 97 & 83 & 83 & 83\end{array}$

Adjusted $\mathrm{R}^{2}$

0.71

0.71

0.78

0.67

0.79

0.76 
Notes $* * *$ : Significant at $1 \%$ level of significance

$* *$ : Significant at $5 \%$ level of significance

$*$ : Significant at $10 \%$ level of significance

Heterosdasticity robust standard errors in parentheses 
Table 5: OLS Regressions of Gini Index 1992-1997, for developing country sample

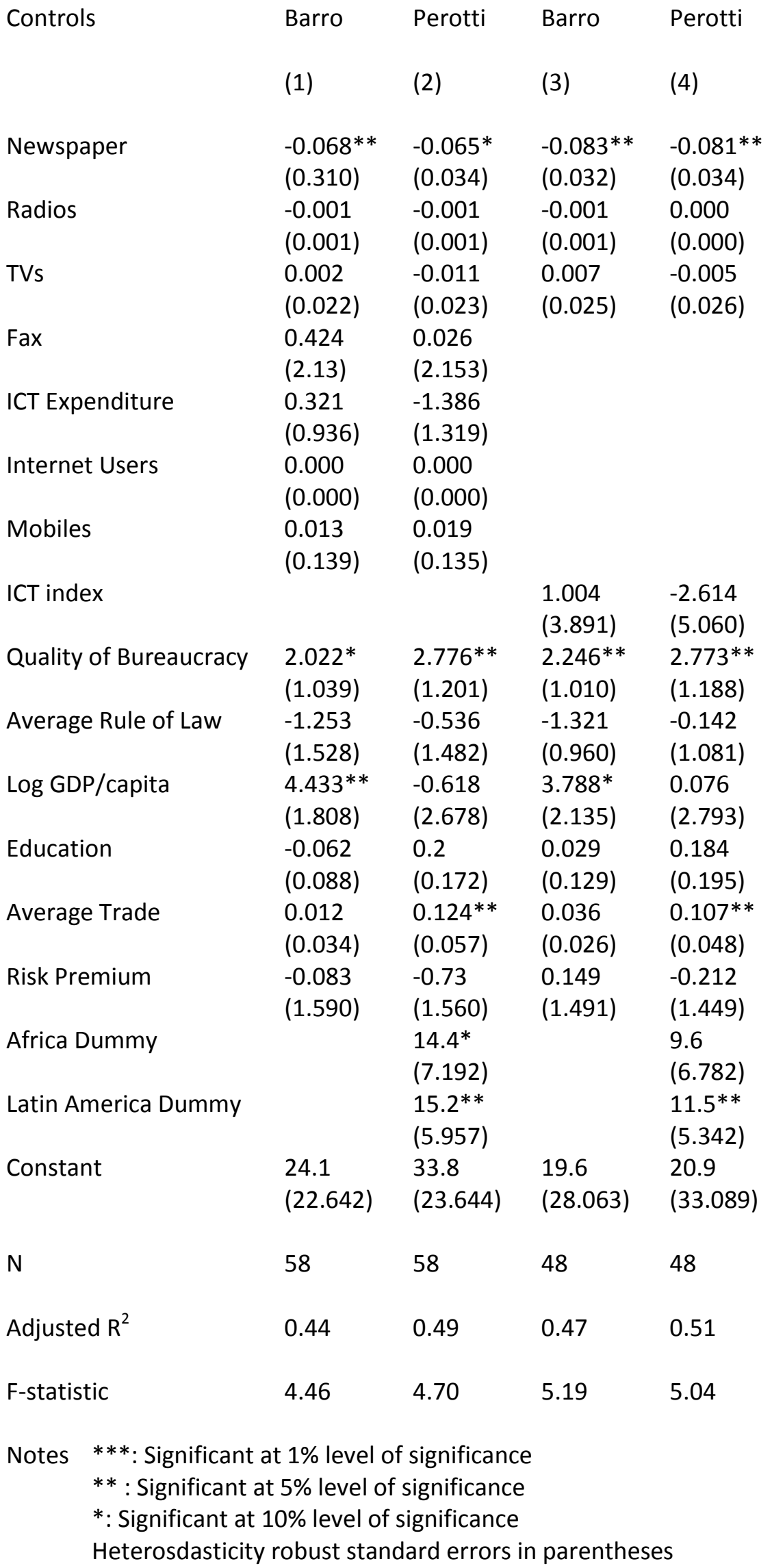


Table 6: OLS Regressions of Poverty 1992-1997, for developing country sample

\begin{tabular}{|c|c|c|c|c|c|c|c|}
\hline Dependent variable & $\begin{array}{l}\text { \$1/day } \\
\text { Poverty }\end{array}$ & $\begin{array}{l}\text { \$1/day } \\
\text { Poverty }\end{array}$ & $\begin{array}{l}\text { \$1/day } \\
\text { Poverty }\end{array}$ & $\begin{array}{l}\text { \$1/day } \\
\text { Poverty }\end{array}$ & $\begin{array}{l}\text { \$2/day } \\
\text { Poverty }\end{array}$ & $\begin{array}{l}\text { \$2/day } \\
\text { Poverty }\end{array}$ & $\begin{array}{l}\text { \$2/day } \\
\text { Poverty }\end{array}$ \\
\hline & (1) & $(2)$ & (3) & (4) & (5) & $(6)$ & (7) \\
\hline Newspapers & $\begin{array}{l}0.031 \\
(0.037)\end{array}$ & $\begin{array}{l}0.127^{* *} \\
(0.031)\end{array}$ & $\begin{array}{l}0.029 \\
(0.028)\end{array}$ & $\begin{array}{l}0.036 \\
(0.034)\end{array}$ & $\begin{array}{l}-0.06 \\
(0.051)\end{array}$ & $\begin{array}{l}0.007 \\
(0.044)\end{array}$ & $\begin{array}{l}0.034 \\
(0.059)\end{array}$ \\
\hline Radios & $\begin{array}{l}-0.018^{*} \\
(0.008)\end{array}$ & $\begin{array}{l}-0.029 * * \\
(0.006)\end{array}$ & $\begin{array}{l}-0.016^{*} \\
(0.007)\end{array}$ & $\begin{array}{l}-0.015^{*} \\
(0.008)\end{array}$ & $\begin{array}{l}-0.034 * * \\
(0.014)\end{array}$ & $\begin{array}{l}-0.045^{* * *} \\
(0.013)\end{array}$ & $\begin{array}{l}-0.045^{* * *} \\
(0.013)\end{array}$ \\
\hline TVs & $\begin{array}{l}0.059 \\
(0.051)\end{array}$ & $\begin{array}{l}0.116^{* *} \\
(0.033)\end{array}$ & $\begin{array}{l}-0.008 \\
(0.021)\end{array}$ & $\begin{array}{l}-0.026 \\
(0.025)\end{array}$ & $\begin{array}{l}-0.127^{* *} \\
(0.042)\end{array}$ & $\begin{array}{l}-0.087^{* *} \\
(0.037)\end{array}$ & $\begin{array}{l}-0.067^{* * *} \\
(0.032)\end{array}$ \\
\hline Fax & $\begin{array}{l}3.753 \\
(2.731)\end{array}$ & $\begin{array}{l}-3.684 \\
(2.468)\end{array}$ & & & $\begin{array}{l}7.426 \\
(4.444)\end{array}$ & & \\
\hline ICT Expenditure & $\begin{array}{l}-0.034 \\
(1.534)\end{array}$ & $\begin{array}{l}3.679 \\
(1.789)\end{array}$ & & & $\begin{array}{l}-4.507^{*} \\
(2.292)\end{array}$ & & \\
\hline Internet Users & $\begin{array}{l}0.000 \\
(0.000)\end{array}$ & $\begin{array}{l}0.000 * * \\
(0.000)\end{array}$ & & & $\begin{array}{l}0.000^{*} \\
(0.0000)\end{array}$ & & \\
\hline Mobiles & $\begin{array}{l}-0.076 \\
(0.250)\end{array}$ & $\begin{array}{l}0.755^{*} \\
(0.279)\end{array}$ & & & $\begin{array}{l}-0.59 \\
(0.375)\end{array}$ & & \\
\hline ICT Index & & & $\begin{array}{l}-1.791 \\
(5.559)\end{array}$ & $\begin{array}{l}4.791 \\
(11.170)\end{array}$ & & $\begin{array}{l}-9.562 \\
(8.049)\end{array}$ & $\begin{array}{l}12.274 \\
(19.144)\end{array}$ \\
\hline Quality of Bureaucracy & $\begin{array}{l}0.432 \\
(1.318)\end{array}$ & $\begin{array}{l}-0.766 \\
(0.958)\end{array}$ & $\begin{array}{l}-2.138^{* *} \\
(0 .\end{array}$ & $\begin{array}{l}-1.628 \\
(1.390)\end{array}$ & $\begin{array}{l}-1.365 \\
(1.731)\end{array}$ & $\begin{array}{l}-2.707 \\
(1.535)\end{array}$ & $\begin{array}{l}-1.988 \\
(1.996)\end{array}$ \\
\hline Average Rule of Law & $\begin{array}{l}-0.691 \\
(2.412)\end{array}$ & $\begin{array}{l}-5.334^{* *} \\
(1.84)\end{array}$ & -0.058 & $\begin{array}{l}0.312 \\
(1.205)\end{array}$ & $\begin{array}{l}5.569 \\
(3.422)\end{array}$ & $\begin{array}{l}1.857 \\
(1.661)\end{array}$ & $\begin{array}{l}0.701 \\
(2.107)\end{array}$ \\
\hline Log GDP/capita & $\begin{array}{l}-9.792^{*} \\
(4.462)\end{array}$ & $\begin{array}{l}-13.542^{* * *} \\
(2.845)\end{array}$ & -2.697 & $\begin{array}{l}-2.210 \\
(3.121)\end{array}$ & $\begin{array}{l}-2.643 \\
(3.462)\end{array}$ & $\begin{array}{l}-3.699 \\
(3.449)\end{array}$ & $\begin{array}{l}-5.815 \\
(5.549)\end{array}$ \\
\hline Education & $\begin{array}{l}-0.334 \\
(0.231)\end{array}$ & $\begin{array}{l}-1.241^{* * *} \\
(0.224)\end{array}$ & $-0.567 * *$ & $\begin{array}{l}-0.629 * * \\
(0.240)\end{array}$ & $\begin{array}{l}0.006 \\
(0.178)\end{array}$ & $\begin{array}{l}-0.875^{* *} \\
(0.344)\end{array}$ & $\begin{array}{l}-1.107^{* *} \\
(0.418)\end{array}$ \\
\hline Average Trade & $\begin{array}{l}-0.105^{* *} \\
(0.044)\end{array}$ & $\begin{array}{l}-0.238^{* * *} \\
(0.050)\end{array}$ & $-0.089 * *$ & $\begin{array}{l}-0.092^{* *} \\
(0.033)\end{array}$ & $\begin{array}{l}-0.109 \\
(0.067)\end{array}$ & $\begin{array}{l}-0.159 * * * \\
(0.042)\end{array}$ & $\begin{array}{l}-0.287^{* * *} \\
(0.108)\end{array}$ \\
\hline
\end{tabular}




\begin{tabular}{|c|c|c|c|c|c|c|c|c|}
\hline \multicolumn{2}{|c|}{ Risk Premium } & $\begin{array}{l}-2.256 \\
(2.002)\end{array}$ & $\begin{array}{l}4.671 \\
(3.563)\end{array}$ & -0.749 & $\begin{array}{l}-1.090 \\
(1.953)\end{array}$ & $\begin{array}{l}-3.939 \\
(3.195)\end{array}$ & $\begin{array}{l}0.658 \\
(2.738)\end{array}$ & $\begin{array}{l}-0.961 \\
(3.104)\end{array}$ \\
\hline \multicolumn{2}{|c|}{ Telephone Mainline Revenue } & $\begin{array}{l}0.028^{* *} \\
(0.012)\end{array}$ & $\begin{array}{l}0.026 * * \\
(0.008)\end{array}$ & & & & & \\
\hline \multicolumn{3}{|c|}{ Telephone Mainlines/Employee } & $\begin{array}{l}-0.017 \\
(0.015)\end{array}$ & & & & & \\
\hline \multicolumn{3}{|c|}{ Africa Dummy } & & & $\begin{array}{l}-0.648 \\
(6.859)\end{array}$ & & & $\begin{array}{l}-22.876 \\
(17.811)\end{array}$ \\
\hline \multicolumn{3}{|c|}{ Latin America Dummy } & & & $\begin{array}{l}1.294 \\
(5.021)\end{array}$ & & & $\begin{array}{l}-10.845 \\
(10.291)\end{array}$ \\
\hline \multicolumn{2}{|c|}{ Constant } & $\begin{array}{l}111.43^{* *} \\
(39.504)\end{array}$ & $\begin{array}{l}178.77 \\
(91.122)\end{array}$ & $105.657^{* *}$ & $\begin{array}{l}110.579 * * \\
(33.882)\end{array}$ & $\begin{array}{l}123.919 * * \\
(45.692)\end{array}$ & $\begin{array}{l}168.349 * * \\
(54.930)\end{array}$ & $\begin{array}{l}245.095^{* * *} \\
(91.116)\end{array}$ \\
\hline \multicolumn{2}{|l|}{ N } & 25 & 21 & 21 & 21 & 25 & 25 & 21 \\
\hline \multicolumn{2}{|c|}{ Adjusted $R^{2}$} & 0.56 & 0.89 & 0.63 & 0.60 & 0.86 & 0.87 & 0.87 \\
\hline \multicolumn{2}{|c|}{ F-statistic } & 3.18 & 12.17 & 4.48 & 3.50 & 12.60 & 11.65 & 12.18 \\
\hline Notes & $\begin{array}{l}* * * \text { : Significant at } 1 \% \mathrm{I} \\
{ }^{* *}: \text { Significant at } 5 \% \text { le } \\
* \text { : Significant at } 10 \% \text { le } \\
\text { Heterosdasticity robus }\end{array}$ & $\begin{array}{l}\text { evel of signi } \\
\text { vel of signif } \\
\text { vel of signif } \\
t \text { standard } €\end{array}$ & $\begin{array}{l}\text { icance } \\
\text { cance } \\
\text { ance }\end{array}$ & . & & & & \\
\hline
\end{tabular}


Table 7 Instrumental Variable Estimations: First stage and second stage estimates

\begin{tabular}{|c|c|c|c|c|c|c|}
\hline \multirow[t]{3}{*}{ Controls } & Perotti & Perotti & Perotti & Barro & Barro & Barro \\
\hline & \multicolumn{4}{|c|}{$\begin{array}{c}\text { Panel A: First Stage Results } \\
\text { (Dependent Variable: Newspaper Circulation) }\end{array}$} & \multirow[b]{2}{*}{ (5) } & \multirow[b]{2}{*}{ (6) } \\
\hline & (1) & $(2)$ & (3) & (4) & & \\
\hline Radios & $\begin{array}{l}0.009 * \\
(0.005)\end{array}$ & $\begin{array}{l}0.009 \\
(0.007)\end{array}$ & $\begin{array}{l}0.008 \\
(0.005)\end{array}$ & $\begin{array}{l}0.169 * * * \\
(0.051)\end{array}$ & $\begin{array}{l}0.009 * \\
(0.005)\end{array}$ & $\begin{array}{l}0.008 \\
(0.005)\end{array}$ \\
\hline TVs & $\begin{array}{l}0.077 \\
(1.59)\end{array}$ & $\begin{array}{l}0.040 \\
(0.161)\end{array}$ & $\begin{array}{l}0.080 \\
(0.156)\end{array}$ & $\begin{array}{l}0.161 \\
(0.192)\end{array}$ & $\begin{array}{l}0.022 \\
(0.150)\end{array}$ & $\begin{array}{l}0.109 \\
(0.152)\end{array}$ \\
\hline ICT index & $\begin{array}{l}29.804 \\
(29.37)\end{array}$ & $\begin{array}{l}50.662 \\
(33.81)\end{array}$ & $\begin{array}{l}0.299 \\
(0.162)\end{array}$ & $\begin{array}{l}39.358 \\
(37.301)\end{array}$ & $\begin{array}{l}51.482 \\
(33.265)\end{array}$ & \\
\hline ICT Index squared & & $\begin{array}{l}43.821 \\
(36.04)\end{array}$ & $\begin{array}{l}3.439 \\
(0.799)\end{array}$ & & $\begin{array}{l}41.594 \\
(34.786)\end{array}$ & \\
\hline Fax & & & $\begin{array}{l}0.000 \\
(0.000)\end{array}$ & & & $\begin{array}{l}0.843 \\
(1.485)\end{array}$ \\
\hline ICT Expenditure & & & $\begin{array}{l}0.098 \\
(0.241)\end{array}$ & & & $\begin{array}{l}1.297 \\
(7.577)\end{array}$ \\
\hline Internet Users & & & & & & $\begin{array}{l}0.000 \\
(0.000)\end{array}$ \\
\hline Mobiles & & & & & & $\begin{array}{l}0.032 \\
(0.299)\end{array}$ \\
\hline Press Freedom & $\begin{array}{l}0.246 \\
(0.787)\end{array}$ & $\begin{array}{l}0.158 \\
(0.784)\end{array}$ & $\begin{array}{l}1.089 \\
(0.893)\end{array}$ & $\begin{array}{l}-1.345^{*} \\
(0.704)\end{array}$ & $\begin{array}{l}0.317 \\
(0.649)\end{array}$ & $\begin{array}{l}0.619 \\
(0.601)\end{array}$ \\
\hline Log RTI Index & $\begin{array}{l}229.883^{* * *} \\
(47.860)\end{array}$ & $\begin{array}{l}221.652^{* * *} \\
(47.956)\end{array}$ & $\begin{array}{l}241.034^{* * *} \\
(59.220)\end{array}$ & $\begin{array}{l}312.697^{* * *} \\
(72.084)\end{array}$ & $\begin{array}{l}220.007^{* * *} \\
(47.108)\end{array}$ & $\begin{array}{l}226.509 * * * \\
(56.990)\end{array}$ \\
\hline Log RPI Score & $\begin{array}{l}-49.520 * * * \\
(11.49)\end{array}$ & $\begin{array}{l}49.968^{* * *} \\
(11.41)\end{array}$ & $\begin{array}{l}-44.050 * * * \\
(14.596)\end{array}$ & $\begin{array}{l}-17.757 \\
(12.322)\end{array}$ & $\begin{array}{l}-48.561^{* * *} \\
(10.596)\end{array}$ & $\begin{array}{l}-51.266 * * * \\
(12.039)\end{array}$ \\
\hline controls & yes & yes & yes & yes & yes & yes \\
\hline continent dummies & yes & yes & yes & yes & yes & yes \\
\hline $\mathrm{N}$ & 46 & 46 & 55 & 29 & 46 & 55 \\
\hline Centred $\mathrm{R}^{2}$ & 0.88 & 0.89 & 0.89 & 0.95 & 0.89 & 0.96 \\
\hline $\begin{array}{l}\text { Anderson's F statistic } \\
p \text {-value }\end{array}$ & 0.000 & 0.000 & 0.000 & 0.000 & 0.000 & 0.000 \\
\hline
\end{tabular}


Panel B: Second Stage Results

(Dependent Variable: Gini Index)
(1)
(2)
(3)
(4)
(5)
(6)

\begin{tabular}{|c|c|c|c|c|c|c|}
\hline Newspapers & $\begin{array}{l}-0.125^{* * *} \\
(0.014)\end{array}$ & $\begin{array}{l}-0.134^{* * *} \\
(0.012)\end{array}$ & $\begin{array}{l}-0.115^{* * *} \\
(0.014)\end{array}$ & $\begin{array}{l}-0.116^{* * *} \\
(0.027)\end{array}$ & $\begin{array}{l}-0.128^{* * *} \\
(0.016)\end{array}$ & $\begin{array}{l}-0.112^{* * *} \\
(0.015)\end{array}$ \\
\hline Radios & $\begin{array}{l}-0.001 * \\
(0.000)\end{array}$ & $\begin{array}{l}-0.001^{* *} \\
(0.000)\end{array}$ & $\begin{array}{l}-0.001^{* *} \\
(0.000)\end{array}$ & $\begin{array}{l}-0.011^{*} \\
(0.006)\end{array}$ & $\begin{array}{l}-0.001^{* *} \\
(0.000)\end{array}$ & $\begin{array}{l}-0.001^{* *} \\
(0.000)\end{array}$ \\
\hline TVs & $\begin{array}{l}-0.014 \\
(0.013)\end{array}$ & $\begin{array}{l}-0.024^{*} \\
(0.013)\end{array}$ & $\begin{array}{l}-0.026^{*} \\
(0.016)\end{array}$ & $\begin{array}{l}0.015 \\
(0.030)\end{array}$ & $\begin{array}{l}0.008 \\
(0.015)\end{array}$ & $\begin{array}{l}0.013 \\
(0.013)\end{array}$ \\
\hline ICT Index & $\begin{array}{l}1.164 \\
(1.987)\end{array}$ & $\begin{array}{l}9.343 * * * \\
(2.652)\end{array}$ & & $\begin{array}{l}3.440 \\
(3.913)\end{array}$ & $\begin{array}{l}8.962 * * * \\
(3.259)\end{array}$ & \\
\hline ICT Index squared & & $\begin{array}{l}15.271^{* * *} \\
(4.024)\end{array}$ & & & $\begin{array}{l}17.063^{* * *} \\
(4.697)\end{array}$ & \\
\hline Fax & & & $\begin{array}{l}-0.502^{* * *} \\
(0.141)\end{array}$ & & & $\begin{array}{l}-0.462^{* * *} \\
(0.144)\end{array}$ \\
\hline ICT Expenditure & & & $\begin{array}{l}0.593 \\
(0.568)\end{array}$ & & & $\begin{array}{l}0.740 \\
(0.884)\end{array}$ \\
\hline Internet Users & & & $\begin{array}{l}0.00001^{* * *} \\
(0.00000)\end{array}$ & & & $\begin{array}{l}0.00001^{* * *} \\
(0.00000)\end{array}$ \\
\hline Mobiles & & & $\begin{array}{l}-0.021 \\
(0.017)\end{array}$ & & & $\begin{array}{l}-0.029^{*} \\
(0.015)\end{array}$ \\
\hline Controls & yes & yes & yes & yes & yes & yes \\
\hline Continent dummies & yes & yes & yes & yes & yes & yes \\
\hline $\mathrm{N}$ & 46 & 46 & 55 & 29 & 46 & 55 \\
\hline Centred $\mathrm{R}^{2}$ & 0.92 & 0.95 & 0.95 & 0.92 & 0.93 & 0.93 \\
\hline F-statistic & 108.00 & 106.42 & 36.43 & 13.62 & 63.00 & 54.05 \\
\hline Hansen's J p-value & 0.008 & 0.003 & 0.020 & 0.006 & 0.007 & 0.035 \\
\hline Cragg-Donald statistic & 15.30 & 14.80 & 18.10 & 9.90 & 15.20 & 18.50 \\
\hline
\end{tabular}

Notes $* * *$ : Significant at $1 \%$ level of significance ** : Significant at $5 \%$ level of significance

$*$ : Significant at $10 \%$ level of significance

Heterosdasticity robust standard errors in parentheses 


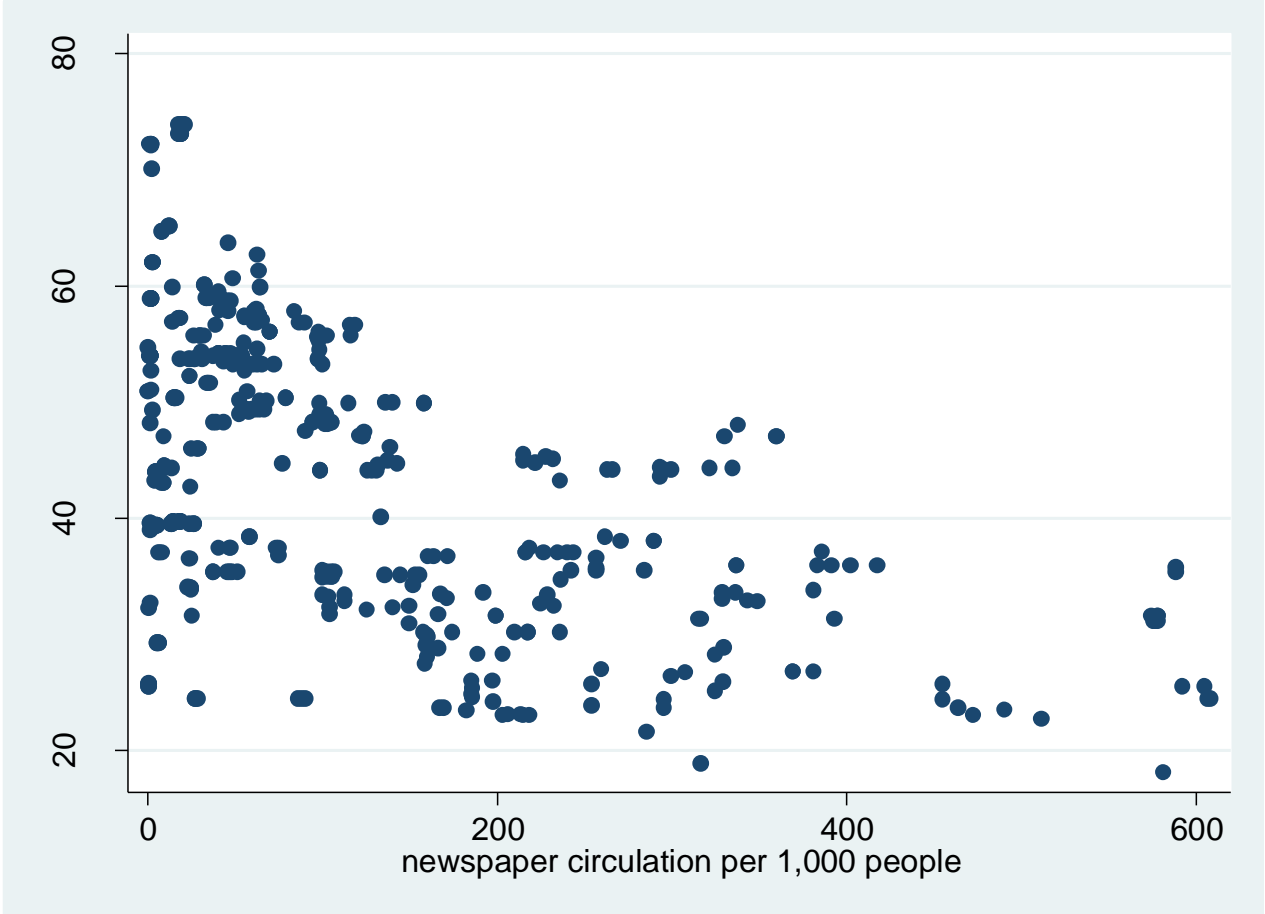

Figure 1 Scatter plot of Gini index on newspaper circulation per 1,000 people, full sample

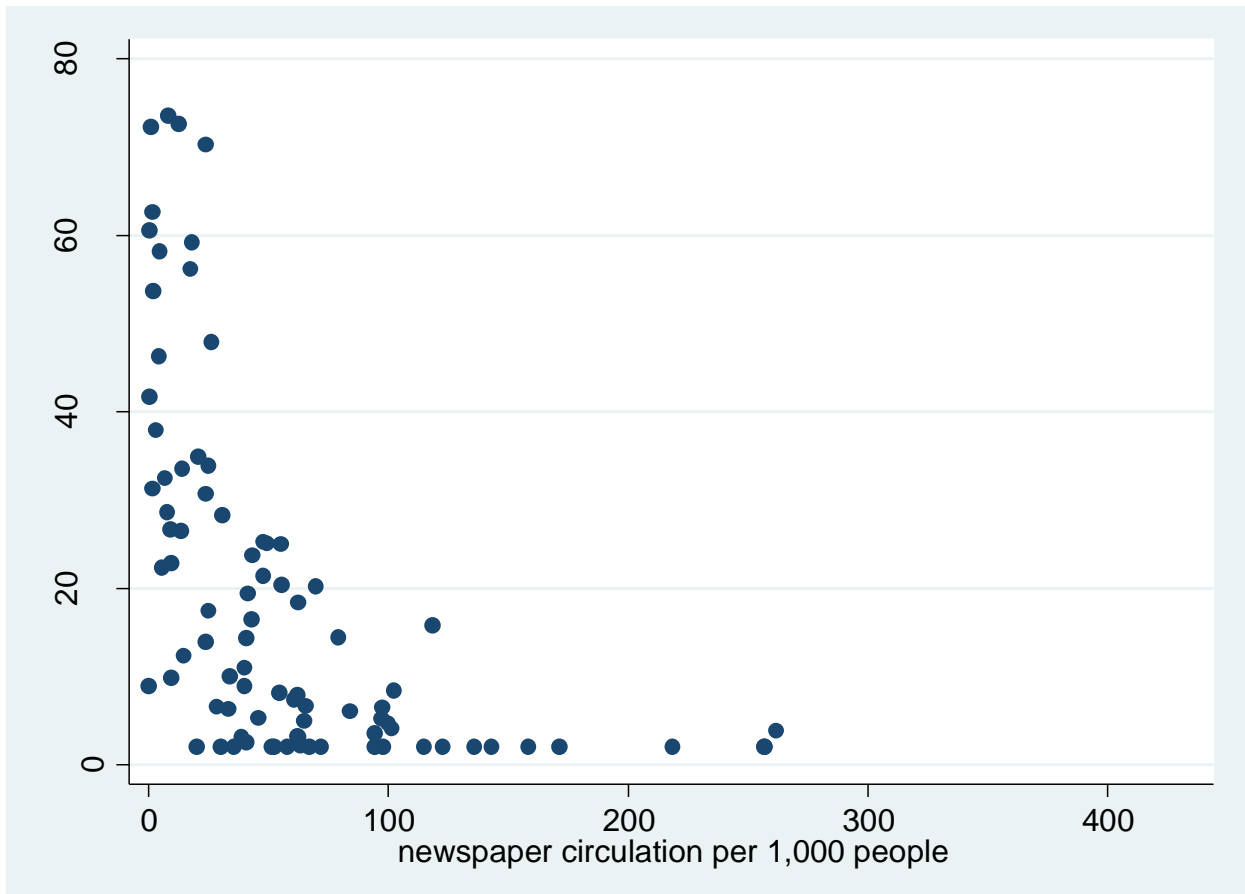

Figure 2 Scatter plot of Poverty $\$ 1$ a day on newspaper circulation per 1,000 people, developing country sample. 


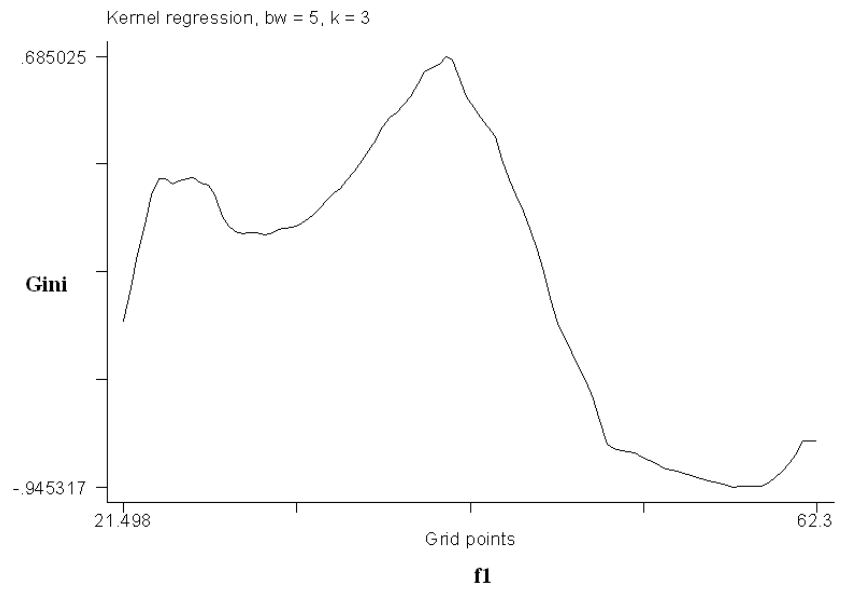

Figure 3 Kernel regression of Inequality on ICT index f1, Epanechnikov kernel

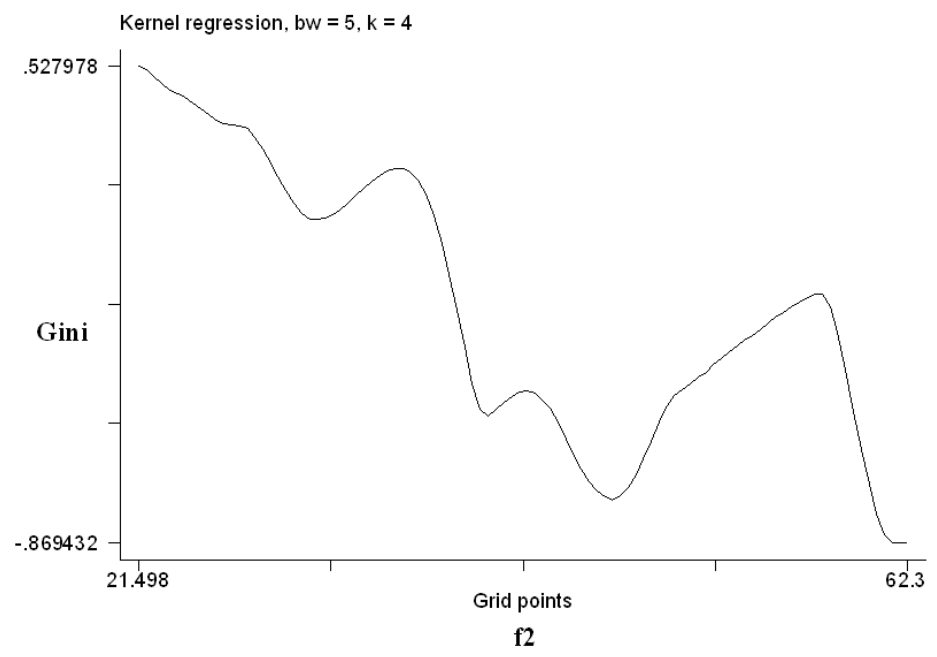

Figure 4 Kernel regression of Inequality on ICT index f2, Epanechnikov kernel 


\section{Appendix: Countries used in the analyses}

$\begin{array}{lllll}\text { Algeria } & \text { El Salvador } & \text { Korea, Republic } & \text { Poland } & \text { Uruguay } \\ \text { Angola } & \text { Ethiopia } & \text { Kuwait } & \text { Portugal } & \text { Venezuela } \\ \text { Argentina } & \text { Finland } & \text { Lebanon } & \text { Qatar } & \text { Vietnam } \\ \text { Australia } & \text { France } & \text { Liberia } & \text { Romania } & \text { Yemen } \\ \text { Austria } & \text { Gabon } & \text { Libya } & \text { Russian Federation } & \text { Yugoslavia } \\ \text { Bahamas } & \text { Gambia } & \text { Luxembourg } & \text { Saudi Arabia } & \text { Zaire/DRC } \\ \text { Bahrain } & \text { Germany } & \text { Madagascar } & \text { Senegal } & \text { Zambia } \\ \text { Bangladesh } & \text { Ghana } & \text { Malawi } & \text { Sierra Leone } & \text { Zimbabwe } \\ \text { Belgium } & \text { Greece } & \text { Malaysia } & \text { Singapore } & \\ \text { Bolivia } & \text { Guatemala } & \text { Mali } & \text { Slovakia } & \\ \text { Botswana } & \text { Guinea } & \text { Malta } & \text { Somalia } & \\ \text { Brazil } & \text { Guinea-Bissau } & \text { Mexico } & \text { South Africa } & \\ \text { Brunei } & \text { Guyana } & \text { Mongolia } & \text { Spain } & \\ \text { Bulgaria } & \text { Haiti } & \text { Morocco } & \text { Sri Lanka } & \\ \text { Burkina Faso } & \text { Honduras } & \text { Mozambique } & \text { Sudan } & \\ \text { Cameroon } & \text { Hong Kong } & \text { Myanmar } & \text { Suriname } \\ \text { Canada } & \text { Hungary } & \text { Namibia } & \text { Sweden } & \\ \text { Chile } & \text { Iceland } & \text { Netherlands } & \text { Switzerland } & \\ \text { China } & \text { India } & \text { New Zealand } & \text { Syria } & \\ \text { Colombia } & \text { Indonesia } & \text { Nicaragua } & \text { Taiwan } & \\ \text { Congo } & \text { Iran } & \text { Niger } & \text { Tanzania } & \\ \text { Costa Rica } & \text { Iraq } & \text { Nigeria } & \text { Thailand } \\ \text { Cote d'Ivoire } & \text { Ireland } & \text { Norway } & \text { Togo } & \\ \text { Cuba } & \text { Israel } & \text { Oman } & \text { Trinidad and Tobago } \\ \text { Cyprus } & \text { Italy } & \text { Pakistan } & \text { Tunisia } & \\ \text { Czech Republic } & \text { Jamaica } & \text { Panama } & \text { Turkey } & \\ \text { Denmark } & \text { Japan } & \text { Papua New Guinea } & \text { UAE } & \\ \text { Dominican Republic } & \text { Jordan } & \text { Paraguay } & \text { Uganda } & \\ \text { Ecuador } & \text { Kenya } & \text { Peru } & \text { United Kingdom } & \\ \text { Egypt } & \text { Korea, DPR } & \text { Philippines } & \text { United States } & \\ & & & & \\ & & & & \end{array}$

The developing country sample consists of the following countries:

$\begin{array}{llll}\text { Algeria } & \text { Gambia } & \text { Morocco } & \text { Yemen } \\ \text { Angola } & \text { Ghana } & \text { Mozambique } & \text { Zaire/DRC } \\ \text { Argentina } & \text { Guatemala } & \text { Myanmar } & \text { Zambia } \\ \text { Bahamas } & \text { Guinea } & \text { Namibia } & \text { Zimbabwe } \\ \text { Bahrain } & \text { Guinea-Bissau } & \text { Nicaragua } & \\ \text { Bangladesh } & \text { Guyana } & \text { Niger } & \\ \text { Bolivia } & \text { Haiti } & \text { Nigeria } & \\ \text { Botswana } & \text { Honduras } & \text { Oman } & \\ \text { Brazil } & \text { India } & \text { Pakistan } & \\ \text { Brunei } & \text { Indonesia } & \text { Panama } & \\ \text { Burkina Faso } & \text { Iran } & \text { Papua New Guinea } \\ \text { Cameroon } & \text { Iraq } & \text { Paraguay } & \\ \text { Chile } & \text { Jamaica } & \text { Peru } & \\ \text { China } & \text { Jordan } & \text { Philippines } & \\ \text { Colombia } & \text { Kenya } & \text { Qatar } & \end{array}$




$\begin{array}{lll}\text { Congo } & \text { Kuwait } & \text { Saudi Arabia } \\ \text { Costa Rica } & \text { Lebanon } & \text { Senegal } \\ \text { Cote d'Ivoire } & \text { Liberia } & \text { South Africa } \\ \text { Cuba } & \text { Libya } & \text { Sri Lanka } \\ \text { Dominican Republic } & \text { Madagascar } & \text { Surinam } \\ \text { Ecuador } & \text { Malawi } & \text { Syria } \\ \text { Egypt } & \text { Malaysia } & \text { Thailand } \\ \text { El Salvador } & \text { Mali } & \text { Trinidad and Tobago } \\ \text { Ethiopia } & \text { Malta } & \text { UAE } \\ \text { Gabon } & \text { Mexico } & \text { Venezuela }\end{array}$

